\section{Federal funding of health policy in Brazil: trends and challenges}

\author{
O financiamento federal da política de saúde no \\ Brasil: tendências e desafios
}

\author{
Financiamiento federal de la política de salud en \\ Brasil: tendencias y desafíos
}

\begin{abstract}
The article analyzes Federal funding of health policy in Brazil in the 2000s, focusing on the Ministry of Health's budget implementation. Federal spending on health was less unstable between 2000 and 2002 and has expanded since 2006. However, it fluctuated as a share of both the Gross Domestic Product and Gross National Revenue. Federal intergovernmental transfers increased, exceeding 70\% in 2007. Meanwhile, the proportion of Federal investments remained low, varying from $3.4 \%$ to $6.3 \%$. The highest absolute amount of spending was on specialized outpatient and hospital care. The decade showed a proportionally greater increase in spending on pharmaceutical care. The growing allocation of Federal funds to States in the North and Northeast, especially for primary care and epidemiological surveillance, failed to offset the sharp regional inequalities in per capita Federal spending. The main characteristics of health funding limit Federal health policy governance and pose several challenges for the Brazilian Unified $\mathrm{Na}$ tional Health System.
\end{abstract}

Healthcare Financing; Health Policy; Federal Government
Cristiani Vieira Machado 1

Luciana Dias de Lima 1

Carla Lourenço Tavares de Andrade 1

\section{Resumo}

O artigo analisa as mudanças na participação federal no financiamento da saúde nos anos 2000, enfocando a execução orçamentária do Ministério da Saúde do Brasil. Observou-se menor instabilidade de 2000 a 2002 e, a partir de 2006, maior crescimento do gasto federal em saúde. Entretanto, o gasto oscilou como proporção do Produto Interno Bruto e das Receitas Correntes Brutas da União. A participação das transferências intergovernamentais aumentou, ultrapassando 70\% em 2007. Já a proporção dos investimentos foi baixa, variando de 3,4\% a 6,3\%, entre 2002 e 2011. O maior volume de gastos correspondeu ao programa de assistência hospitalar e ambulatorial especializada e o maior aumento relativo, à assistência farmacêutica e insumos estratégicos. Identificaram-se esforços quanto à desconcentração de recursos para regiões mais carentes - por meio dos programas de atenção básica e vigilância - que não foram suficientes para superar as desigualdades regionais existentes. As características do financiamento da política de saúde limitam a governabilidade federal e colocam desafios ao SUS.

Financiamento da Assistência à Saúde; Política de Saúde; Governo Federal 


\section{Introduction}

The increase in national states' responsibilities in the social area was an important phenomenon in the $20^{\text {th }}$ century, related to transformations in world capitalism and the expansion of social rights 1 . The state played a growing role in financing by collecting taxes and implementing the public budget, thereby contributing to the "de-commodification" of access to actions and services covered by social policies, with differences between countries ${ }^{2}$.

Health and social security are the social policy areas that traditionally mobilize the most resources. It was no coincidence that they were the most heavily strained by reforms in social protection systems in the advanced 3 and Latin-American countries ${ }^{4}$, respectively, since the 1970 s and 1980s.

Brazil's 1988 Constitution provided advanced guidelines for social protection (including the areas of social security/retirement pensions, health, and social assistance) and established the Brazilian Unified National Health System (SUS), which is public and has universal coverage. However, in subsequent years the implementation of Constitutional guidelines on social protection and health was hindered by a series of historical, structural, and contextual obstacles, including difficulties in financing social policies 5 .

Numerous studies have explored the limits and impasses of health financing in the context of implementing the SUS in the 1990s, related to restrictions on the financing of social policies, fluctuations in funding sources, weak investment policy, instability in the provision of funds from the Brazillian Ministry of Health, and financial disparities between States and municipalities, among other factors 6,7,8,9,10.

Brazil shows low per capita public expenditure in health and low governamental expenditure on health (as a proportion of total governmental expenditure), even compared to some other Latin American countries such as Argentina and Chile 11. The large relative weight of private health expenditure in the country (estimated at $56.4 \%$ of total spending in 2009) is hardly consistent with the public and universal model proposed by the SUS. This reflects structural problems in public-private relations and reveals the perverse side of health sector financing, as expressed by tax subsides for private health expenditures, government spending on private health plans for public employees, and out-ofpocket health spending by the poorest families 12 , all leading to the unequal use of health services based on income profiles 13 .
The 1988 Constitution provides that the three levels of government (Federal, State, and Municipal) have the responsibility to participate in health financing. Importantly, the relative weight of the Federal government in public spending in health decreased from more than $70 \%$ in the early 1990 s to $44.7 \%$ in 201014 due to increased participation by the other two levels, especially the Municipalities in the 1990s and more recently the States 14,15. The decrease in the Federal government's relative share of health sector financing is partially explained by the decentralization process and the establishment of stricter rules for earmarking budget funds for health at the subnational levels since 2000.

Meanwhile, this raises two major concerns involving the Brazilian Ministry of Health's role in health sector financing. First, the Brazilian Federal system is historically marked by the importance of the National Executive Branch, which persisted even in the post-1988-Constitutional context of decentralization of public policies 16,17. Second, there are huge economic, social, and health-related heterogeneities in Brazil, heavily expressed in health. Health system decentralization differed greatly among the States and Municipalities in terms of institutional and financial capacities and dependence on Federal transfers 9,18,19,20.

In this context, Federal government needs to play a redistributive role and develop policies focused on reducing inequalities. Comparative studies show that maintenance of citizens' rights at the national level is a characteristic function of central governments in various Federal systems that have undergone important decentralization in public expenditure in health in recent decades 21,22,23.

Considering the Federal government's strategic responsibility in the implementation of a universal and public health system in Brazil, the study sought to investigate the recent changes in the Federal government's participations in financing the SUS, focusing on an analysis of the characteristics of the Brazilian Ministry of Health's budget outlay in the 2000s. The final section discusses several conditioning factors and challenges related to the Federal government's role in health financing, based on the study's results and the existing literature.

\section{Methods}

The study focused on Federal expenditures by the Brazilian Ministry of Health, which in 2009 represented some $46 \%$ of public spending and $20 \%$ of total health spending in Brazil, consid- 
ering estimated shares for the three levels of government according to other authors 14 and information on the public-private proportions of spending for that year provided by the World Health Organization 11.

The data analyzed here were obtained from national databases or furnished directly by the Brazilian Ministry of Health, and refer mainly to the 2000s, given the study's focus and limits in data availability and comparability, as explained below.

Analysis of Federal financing included the following lines: (a) trends in the amount of Federal health funds; (b) Federal health spending as a proportion of the Gross Domestic Product (GDP) and Gross National Revenue (GNR); (c) form of expenditure of funds by the Ministry (intergovernmental transfers or direct outlay); and (d) destination of the funds by groups of expenses, programs, and States.

Data on Federal budget spending for 1995 to 2001 were obtained directly from the Executive Secretariat of the Brazilian Ministry of Health. For the years 2002 to 2011, data were obtained from the Information System on Plans and Public Budget (SIGA), available on the Brazilian Senate's website (http://www9.senado.gov.br/ portal/page/portal/orcamento_senado/SigaBrasil). Meanwhile, the data on the Federal share of total public spending were calculated using data from the SIGA database (Federal expenditures) and the Information System on Public Budgets in Health - SIOPS (expenditures by States and Municipalities, http://siops.datasus.gov.br).

The study only analyzed the budget outlay on health actions and services. Thus, payments for public employees retirements, pensions, debt service, and other types of expenditures listed on the health budget in specific years (the fund to fight poverty and conditional cash transfers) were not included. The study used the funds earmarked for each year, which were mostly close to the amounts actually spent. To analyze annual trends, funds were adjusted for inflation according to the Expanded National Consumer Price Index (CPI) of the Brazilian Institute of Geography and Statistics (IBGE).

As for expenditures on health programs, the study only included data obtained in SIGA for the period from 2004 to 2011. It did not include data for the previous years because of the article's focus on the 2000s, limited availability (SIGA only presents data beginning in 2002), or comparability issues. The latter related to changes in the grouping of budget programs in 2004, resulting from changes in the Brazilian Ministry of Health's administrative structure in the previous year and the beginning of the Pluri-Annual Planning cy- cle (PPA) from 2004 to 2007. Data from 2008 to 2011 required adjustments, due to changes in the nomenclature and grouping of programs in the 2008-2011 PPA cycle.

Analysis by States of the country included the portion of the budget that was subject to regional appropriation, which in 2002-2011 corresponded to some $63 \%$ to $70 \%$ of the Brazilian Ministry of Health's budget. This portion includes costing or investment expenditures for which the destination to regions or States is known, such as transfers to other levels of government, direct payments to providers, agreements, or Congressional amendments. In general, it does not include expenditures on central administration of Federal agencies or programs, payroll, expenditures for public employees retirements or pensions, debt payments, or other special operations.

The maps in Figure 4 were built with MapInfo (MapInfo Corp., New York, USA), based on classification in quartiles for the variables "percentage variation in Federal spending from 2002 to 2011", "per capita Federal health spending in 2011", and "Federal percentage share of public expenditure on health in 2011 ".

\section{Results}

Analysis of the Brazilian Ministry of Health's budget outlay on health actions and services from 1995 to 2011 (as measured by amounts of funds) shows fluctuations, particularly in the latter half of the 1990s (Figure 1). From 1999 to 2002, the amount of Federal health funds increased slightly, with relative stability, which could be related to political struggles and the approval of Constitutional Amendment 29 in the year 2000.

The early Lula Administration (2003 to 2005), in a context of economic constraints, witnessed new fluctuations. Beginning in 2006, there was a steady upward trend in the amount of Federal spending on health actions and services. Even the vote by the National Senate in 2007 not to extend the CPMF (a bank transaction tax in force since 1996 and an important source of tax revenue for the health sector) did not jeopardize the increase in Brazilian Ministry of Health budgetary funds.

This upward trend in the Brazilian Ministry of Health's budget in the latter half of the 2000s was due partly to the country's overall economic growth and the kind of earmarking provided by Constitutional Amendment 29 for Federal expenditures. The prevailing rule for setting the Federal health budget each year considers the outlay from the previous year and the variation in the GDP. 
Figure 1 thus shows Federal health expenditures as a proportion of GDP and GNR, in order to illustrate the degrees of "macroeconomic priority" and "fiscal priority" 24 , assigned to health by the Federal government.

From 1995 to 2011, despite the increase in the Brazilian Ministry of Health's budget in absolute terms, Federal health expenditures as a share of GDP fluctuated, generally between 1.60 and $1.75 \%$, with the lowest level in 1996 (1.47\%) and the highest in 2009 (1.80\%). Meanwhile, the health sector's share of the Federal government's current revenue fluctuated even more drastically during the same period, dropping from $9.64 \%$ in 1995 to $7.02 \%$ in 2011. As shown in Figure 1, in the late 1990s and in the 2000s, Federal spending on health failed to proportionally accompany the growth in national tax revenue.

As for the outlay of Brazilian Ministry of Health budget, Figure 2 shows that the first decade of the $21^{\text {st }}$ century witnessed a growth in Federal transfers from the National Fund to the State and Municipal health funds ("fund-to-fund transfers"). There was a steady increase in the total amount of Federal funds transferred to the subnational levels, exceeding 40 billion BR \$ (approximately $\mathrm{U} \$ 20$ billion) in 2010 . In addition, the share of transfers in the Ministry's outlay on health actions and services increased from $51.0 \%$ in 2002 to $70.2 \%$ in 2010 . In the last year in the series, the share dropped to $68.9 \%$, possibly because the amount of transfers failed to accompany the total budget growth. At the end of the period, the share of the budget spent directly by the Ministry was limited mainly to expenditures on payroll, administration of national programs, and costs of the Ministry's own agencies and services.

The proportion of transfers exceeded $70 \%$ in 2007, after publication of the Pact for Health and the creation of large financing blocks that combine various mechanisms for Federal transfers through the SUS. The modality of direct Federal payment to outpatient and hospital providers practically ceased to exist. Beginning in 2009, even Federal investment funds, previously spent through agreements with States, Municipalities, or providers, were now transferred partially through a specific block of transfers.

This does not mean that States and Municipalities have wide autonomy to spend the transferred funds. Transfers to specific national programs are still subject to conditions and binding clauses as forms of Federal induction and regula-

Figure 1

Trend in budgetary outlays by the Brazilian Ministry of Health on health actions and services, in actual values, as a proportion of Gross Domestic Product (GDP) and Gross National Revenue (GNR). Brazil, 1995-2011.

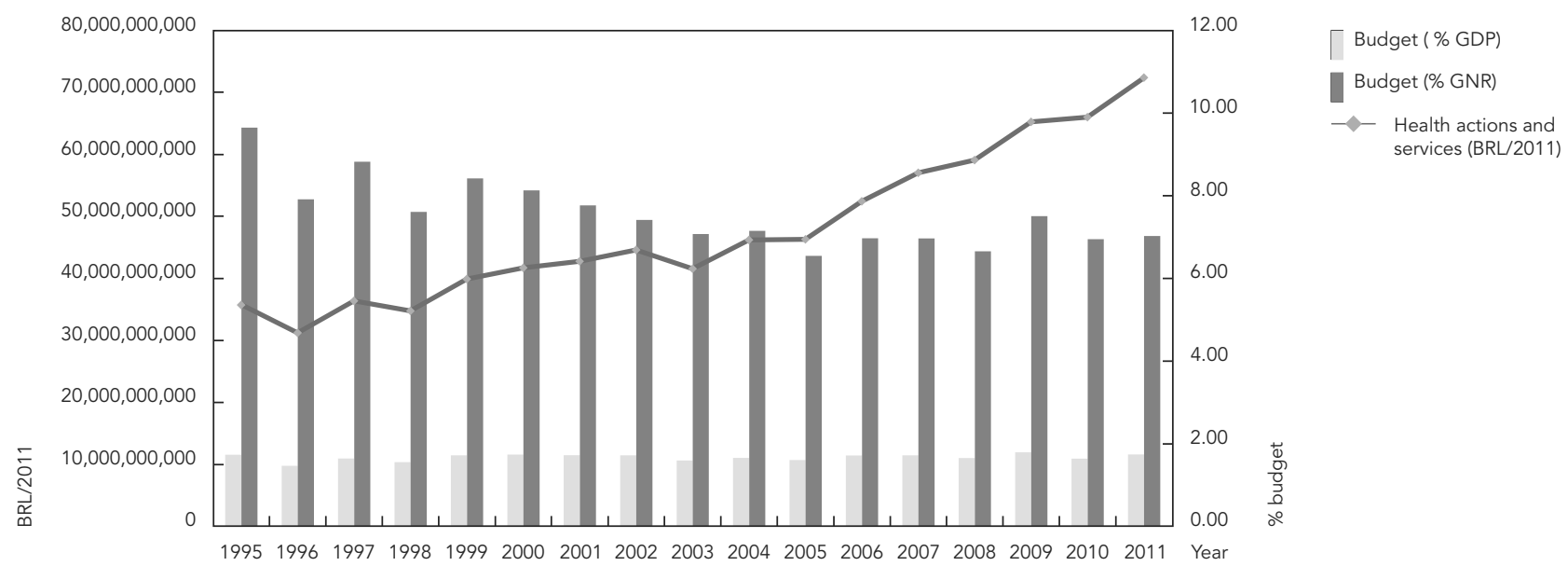

Source: Brazilian Ministry of Health budget: 1995-2001 - Executive Secretariat, Ministry of Health; 2002-2011 - SIGA Brasil, GDP: Ipeadata; GNR: Secretariat of the National Treasury, Ministry of Finance. Figure prepared by the authors.

Note: Earmarked funds, adjusted to December 2011 values by the Expanded National Consumer Price Index (IPCA) of the Brazilian Institute of Geography and Statistics. 


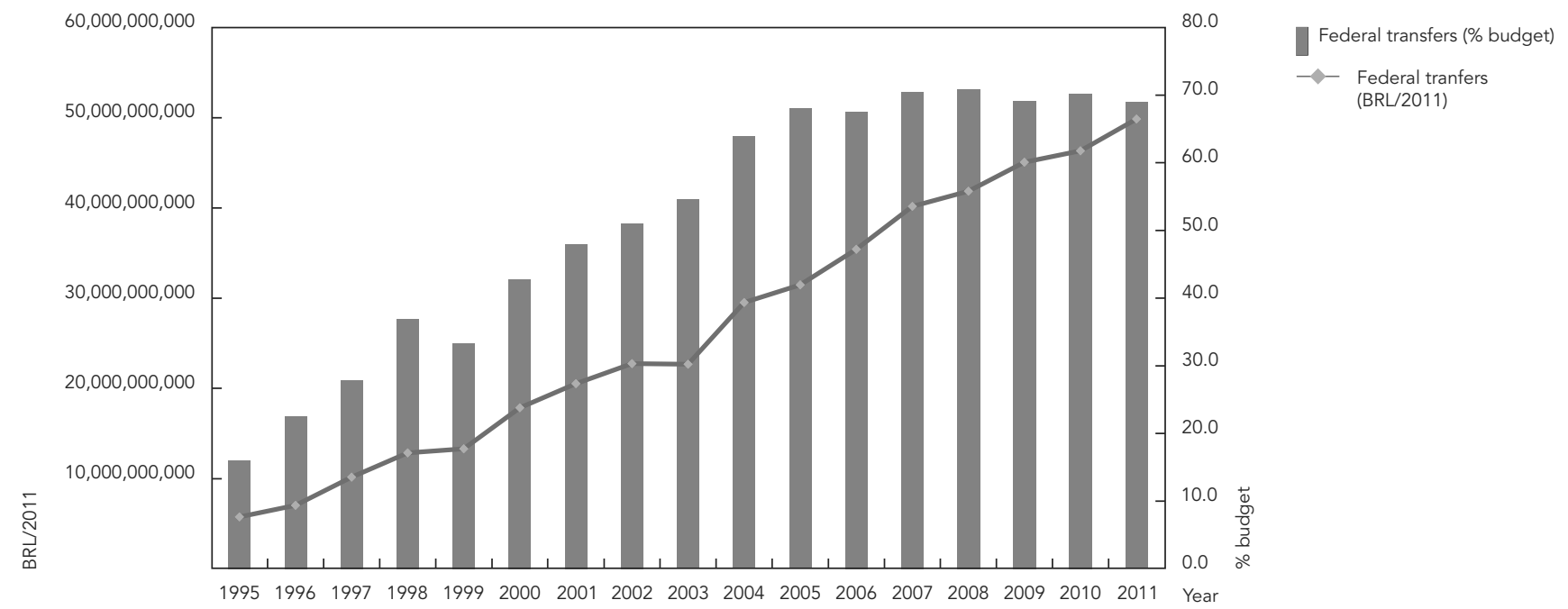

Source: From 1995 to 2001 - Executive Secretariat/Ministry of Health. From 2002 to 2011 - Data from SIGA Brasil. Figure prepared by the authors.

Note: Earmarked funds, adjusted to December 2011 values by the Expanded National Consumer Price Index (IPCA) of the Brazilian Institute of Geography and Statistics (IBGE).

tion of subnational levels. Given the persistently relevant weight of Federal funds and the Brazilian Ministry's influence on their use, it is important to analyze the distribution of these funds, considering the groups of expenses, health programs, and territorial distribution.

As for groups of expenses, investments represent a persistently low share of the Brazilian Ministry of Health's budget, ranging from $3.4 \%$ to $6.3 \%$ of the earmarked budget for health actions and services in 2002-2011. Considering the amounts actually paid out, these percentages were even lower (from $0.5 \%$ to $2.1 \%$ ). Investments are generally the most heavily jeopardized group in health budget spending, with the lowest ratios between earmarked amounts and outlays.

Figure 3 shows the distribution of the Ministry's spending on health programs. For most years between 2004 and 2011, five programs accounted for more than $90 \%$ of Federal spending on health actions and services: specialized outpatient and hospital care (ranging from 47.7 to $50.7 \%$ ); primary care (14.3 to $17.7 \%$ ); administrative support/payroll (10.4 to $13.1 \%$ ); pharmaceutical care and strategic inputs (5.6 to $9.5 \%$ ); and epidemiological surveillance (4.8 to $8.5 \%$ ).
The programs with the largest relative increase in spending during the study period were pharmaceutical care and strategic inputs (up $151.5 \%$ ) and primary care (up 93.1\%). The first of these featured the creation of a specific secretariat in Brazilian Ministry of Health and the expansion of various activities in pharmaceutical care, both in existing areas (e.g., special medication, essential drug list) and those related to new government priorities (e.g., the so-called Popular Pharmacy program). As for primary care, the largest relative increase involved the continued expansion of the Family Health Strategy.

The rate of increase in spending on outpatient and hospital care was similar to that of the overall budget, although the absolute growth was important given this program's weight in the budget.

Meanwhile, spending on epidemiological surveillance increased little during the period, despite the creation of the Health Surveillance Secretariat in 2003, which raised expectations for expanding and strengthening activities in this area. The creation of a new secretariat focusing on Work Management and Health Education also favored greater budget programming for this field. 
Figure 3

Trend in the share of principal programs in the Brazilian Ministry of Health's budgetary outlays on health actions and services. Brazil, $2004-2011$.

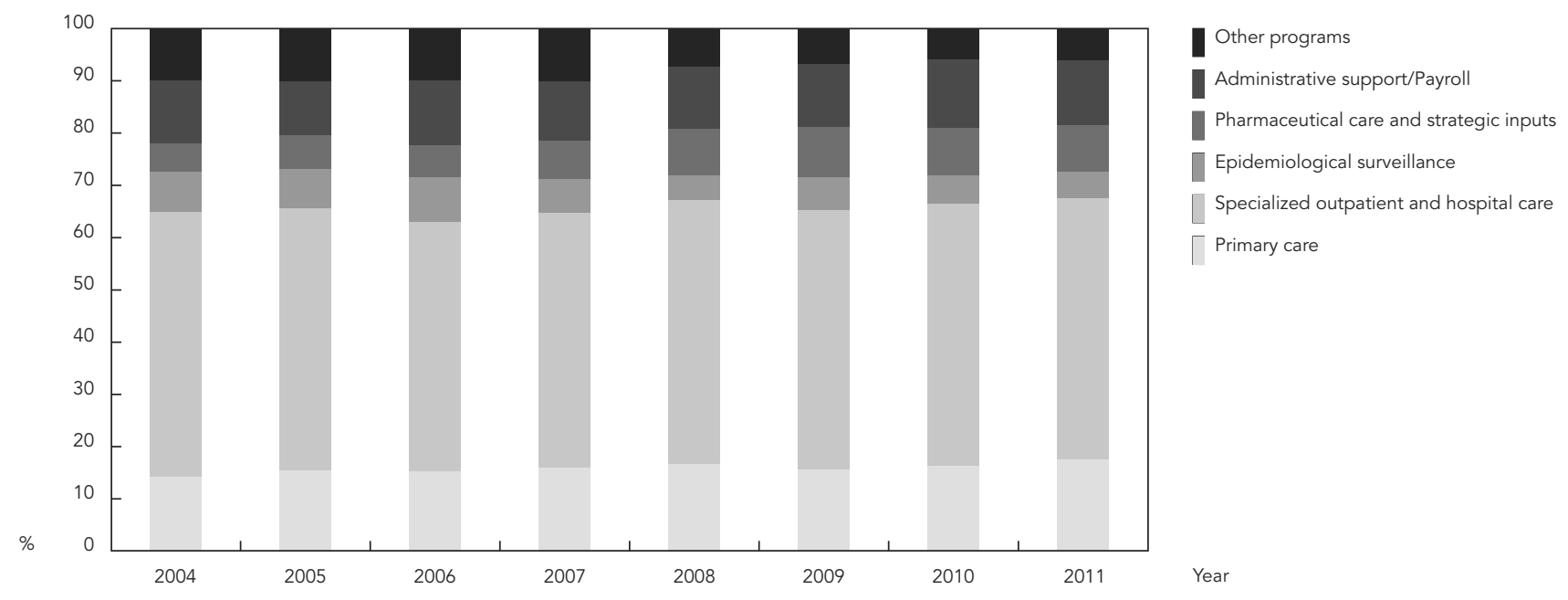

Source: SIGA Brasil. Figure prepared by the authors.

Note: Earmarked funds, adjusted to December 2011 values by the Expanded National Consumer Price Index (IPCA) of the Brazilian Institute of Geography and Statistics (IBGE).

However, from 2004 to 2011 there were difficulties and fluctuations in spending by the two main component programs (work management and health education, which Figure 3 groups under "other programs"), which in the latter case may be partially related to policy changes that altered the rules for spending the funds.

A final approach in the analysis of health financing relates to the distribution of Federal funds among the States, considering the portion of the health budget subject to regional appropriation. Figure 4 shows the Federal budget outlay by States and the Federal District, considering three indicators: variation in Federal spending from 2002 to 2011; per capita Federal health spending in 2011, and Federal share of public health spending in 2011. While the first indicator illustrates the Federal role in the redistribution of funds, the second shows the real situation of inequalities between States in relation to Federal expenditures and the third expresses the differences in the Federal participation on public expendutures on health between the States.

With few exceptions from 2002 to 2011, the increase in the Brazilian Ministry of Health's budget outlay was generally larger in the States of the North and Northeast, while most States of the Southeast and South showed smaller increases (Figure 4a). This suggests an effort to earmark Federal funds for historically underprivileged regions, which may be partially related to the increase in the supply of health actions and services and greater adherence to Federal programs by some States in these regions. However, the analysis in terms of per capita Federal funds (Figure 4b) shows that in 2011 there were persistent inequalities in the allocation of Federal health expenditures to the States, and most States in the North of Brazil received fewer Federal funds that the others.

As for the Federal share of public health spending, there was a decrease from 2002 to 2011 in all the States except Amapá and Amazonas. Even so, Figure 4c illustrates the diversity in the weight of Federal spending in the different States in 2011, varying from $21.0 \%$ (Acre) to $47.9 \%$ (Piauí). In no State was the Ministry of Health's share in health sector financing greater than $50 \%$; in seven States, the share was less than $30 \%$.

Table 1 aims to help explain Federal health financing in Brazil in 2011 by showing State-byState per capita Federal spending on the four main budget programs: primary care, specialized outpatient and hospital care, pharmaceutical care and strategic inputs, and epidemiological surveillance.

In all States and the Federal District, the program with the highest per capita Federal expenditure is specialized outpatient and hospital care, followed by primary care. For the other two pro- 
Brazilian Ministry of Health budgetary outlays in the States and Federal District: variation in Federal spending from 2002 to 2011 (\%), per capita Federal health spending in 2011 (BRL) and Federal share of public expenditures on health in 2011 (\%).

4a) Variation (\%) of Federal spending from 2002 to 2011

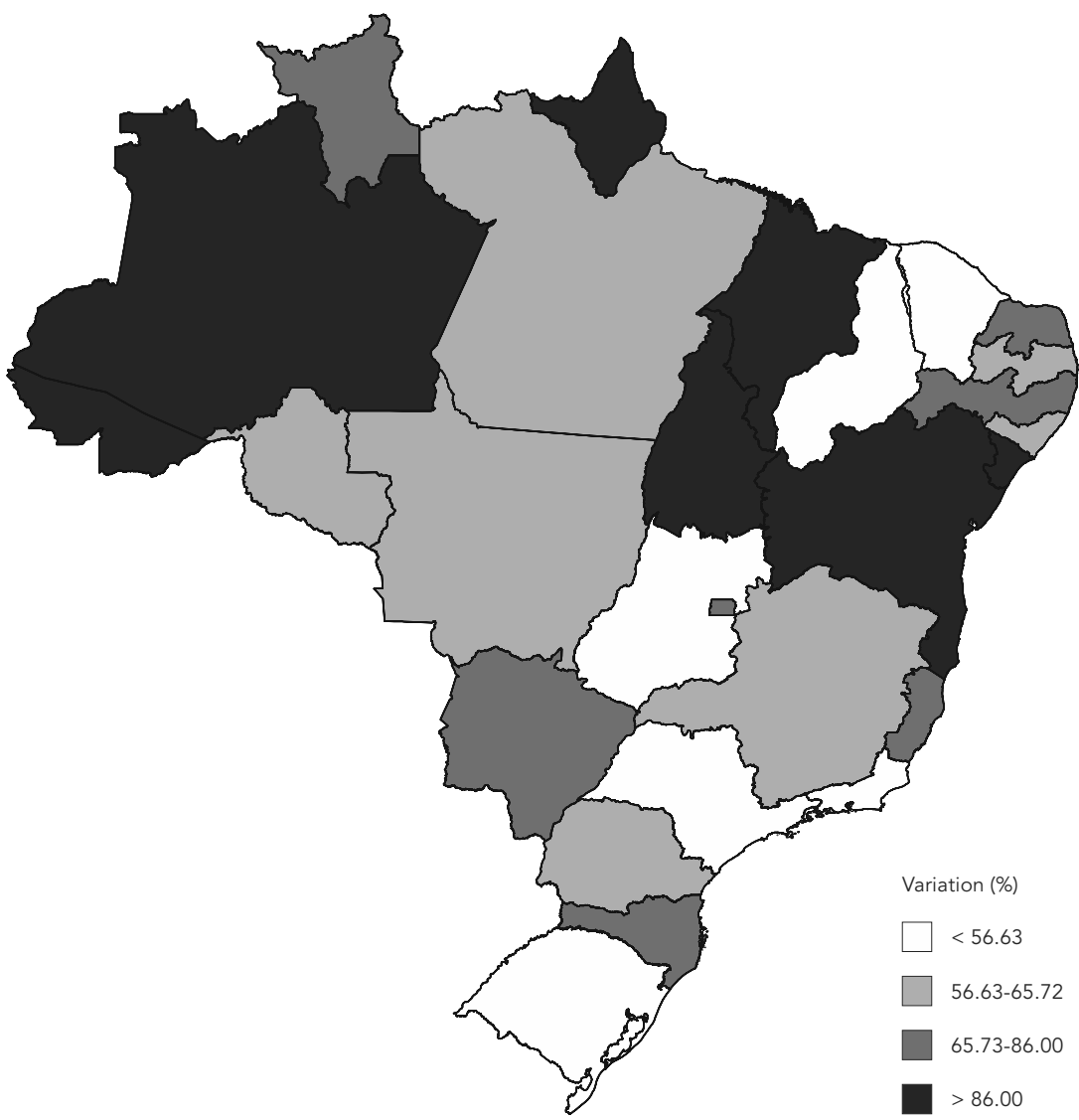

(continues)

grams, per capita Federal spending on epidemiological surveillance exceeds that of pharmaceutical care in all States of the North plus Maranhão. In all other States of Brazil, spending on pharmaceutical care and strategic inputs exceeds that of epidemiological surveillance. Importantly, a relevant share of the Federal funds for pharmaceutical care and epidemiological surveillance are still spent nationwide by the Brazilian Ministry of Health itself, while the other two programs mobilize larger amounts of funds, which are spent predominantly through decentralization.

The comparison between States shows that the Federal redistributive effort is more striking in primary care and epidemiological surveil- lance. In primary care, the highest per capita Federal expenditures were in the States of the Northeast, which is also influenced by the fact that the States and municipalities in that region of Brazil participated more in national programs such as Family Health. In epidemiological surveillance, the highest expenditures were in the States of the North and some in the Northeast (Maranhão) and Central West (Mato Grosso and Mato Grosso do Sul), influenced in part by their epidemiological profile and by the importance of Federal activities involving diseases under surveillance in these States.

Finally, per capita Federal spending on specialized outpatient and hospital care and phar- 


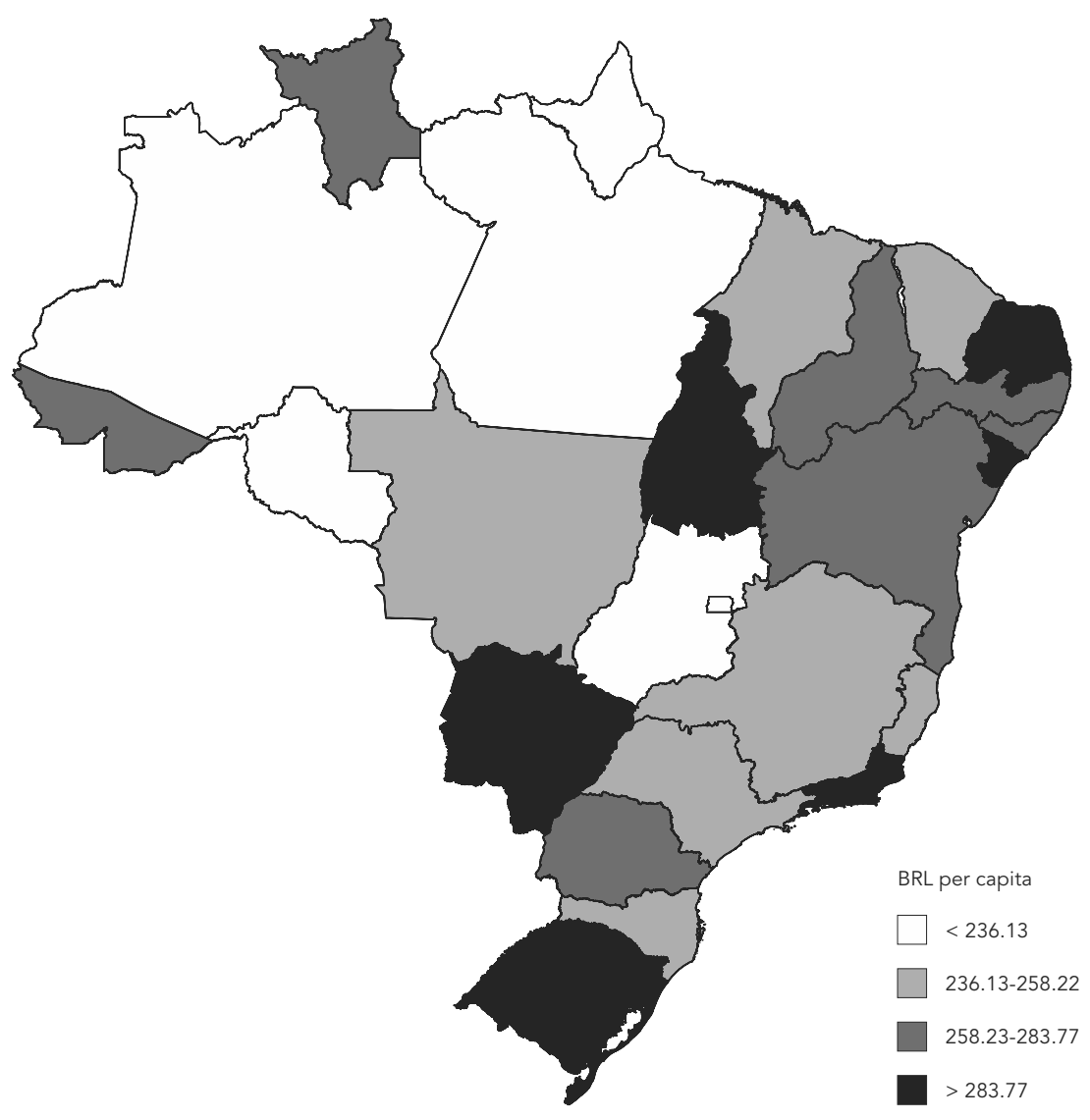

(continues)

maceutical care and strategic inputs was highest in the South and Southeast regions, followed by the Central West, with lower expenditures in the Northeast and North, thus reflecting inequalities in the supply and utilization of healthcare services in the country.

\section{Discussion}

Previous studies have shown that fluctuations in Federal financing in the late 1990s were influenced by restrictive economic policies for public spending and lack of definition of stable sources of health financing ${ }^{8}$. It has already been shown that the approval of the CPMF bank transaction tax in 1996 was not sufficient to guarantee a major increase in Federal funds in real terms, but it did apparently guarantee a certain degree of sta- bility in Federal financing in subsequent years 14 The lack of a more significant increase in the volume of Federal funds following the approval of the CPMF tax was due to shifts in revenue sources. Conflicts persisted over application of the CPMF tax even after approval of Constitutional Amendment 29 in 2000 [which obligated minimum spending on health at the Federal, State, and Municipal levels] ${ }^{8}$. In reality, in terms of the Federal government's funding obligation, tied to variation in the GDP, the amendment's formula apparently failed to favor an increase in Federal funds at that time 6,7, perhaps because the amendment's main objective was to expand State expenditures.

This study corroborated previous research on the first decade of the $21^{\text {st }}$ century, showing a period of lower instability in health financing from 2000 to 2002, possibly favored by previous 


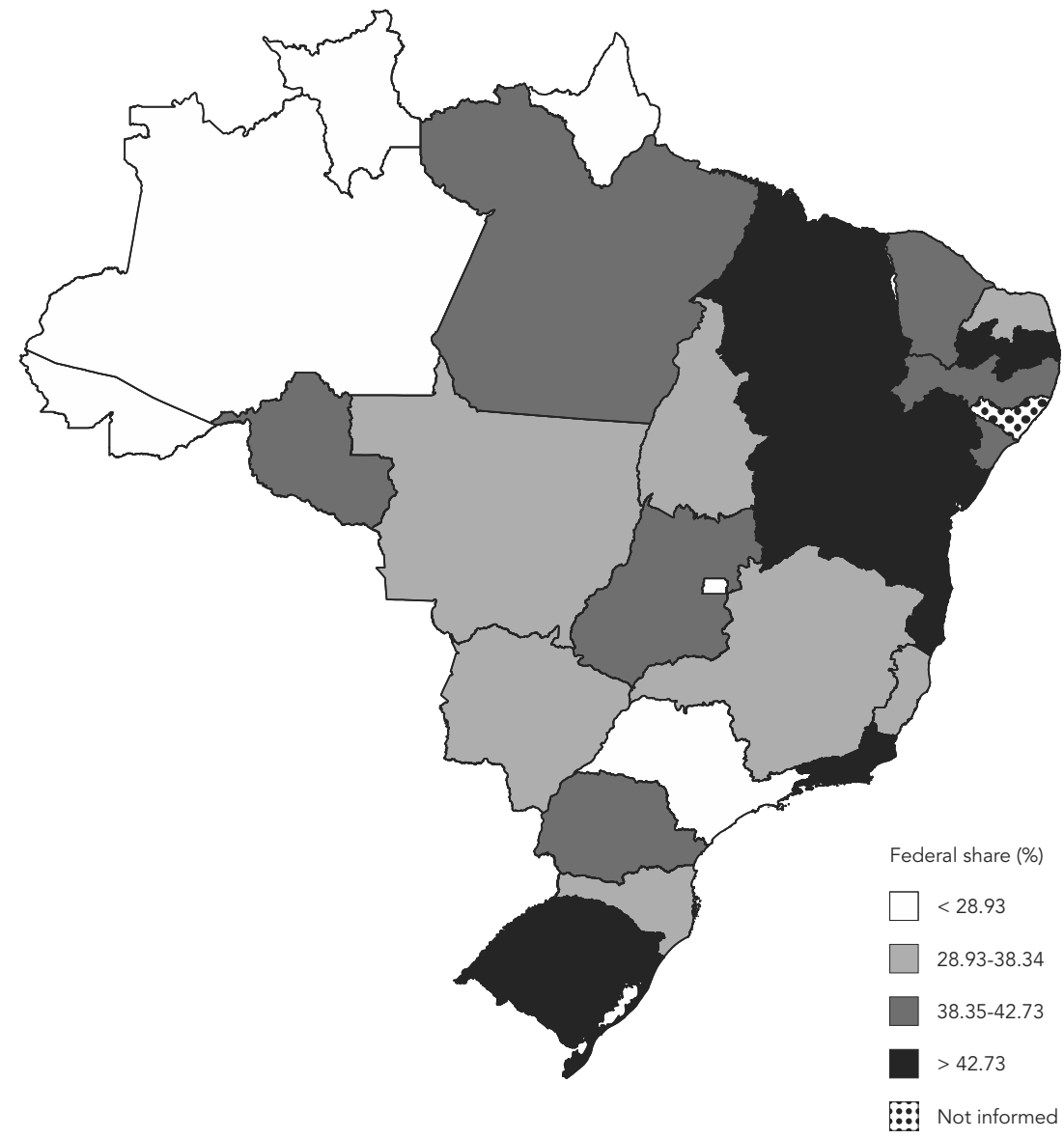

Source: Brazilian Ministry of Health budgetary outlays - SIGA Brasil, State and Municipal expenditures (used to calculate Federal share of total public spending) - SIOPS (Information System on Public Health Budgets), Brazilian population: Brazilian Institute of Geography and Statistics (IBGE). Figure prepared by the authors.

Note: (a) Earmarked resources, considering only expenditures subject to appropriation by the States, Federal District, and Municipalities. (b) variation calculated according to funds adjusted to December 2011 values by the Expanded National Consumer Price Index (IPCA) of the IBGE.

advances, the approval of Constitutional Amendment 29 in 2000, and the Health Minister's political weight in the Federal government. However, Brazil did not experience a more important increase in Federal health spending until 2006, initially due to resumption of the country's economic growth.

According to estimates by the Institute of Applied Economic Research (IPEA) 24, during most of the period analyzed here, Federal spending on health showed a cyclical pattern, fluctuating ac- cording to the acceleration or deceleration of the economy, as measured by GDP. In 2009, health spending showed countercyclical behavior, i.e., despite the drop in GDP resulting from the international economic crisis, the Brazilian Ministry of Health's budget outlay grew in absolute terms and as a proportion of the GDP. This was also true for social spending as a whole, supporting the Federal government's argument in favor of adopting countercyclical policies to withstand the international financial crisis 24 . 
Table 1

Per capita Federal spending (in BRL) on the principal budget programs according to regions of Brazil, States, and Federal District, 2011.

\begin{tabular}{|c|c|c|c|c|}
\hline Region/State & Primary care & $\begin{array}{l}\text { Specialized outpatient } \\
\text { and hospital care }\end{array}$ & $\begin{array}{l}\text { Pharmaceutical care and } \\
\text { strategic inputs }\end{array}$ & $\begin{array}{l}\text { Epidemiological } \\
\text { surveillance }\end{array}$ \\
\hline North & 68.2 & 133.2 & 7.3 & 11.5 \\
\hline Acre & 77.3 & 173.8 & 6.8 & 13.0 \\
\hline Amapá & 74.7 & 126.1 & 7.1 & 14.3 \\
\hline Amazonas & 66.7 & 134.2 & 6.9 & 14.3 \\
\hline Pará & 61.0 & 115.2 & 7.1 & 9.9 \\
\hline Rondônia & 68.1 & 142.2 & 8.8 & 10.4 \\
\hline Roraima & 71.7 & 171.1 & 9.3 & 16.7 \\
\hline Tocantins & 102.1 & 181.9 & 7.4 & 10.3 \\
\hline Northeast & 81.2 & 164.0 & 9.5 & 6.9 \\
\hline Alagoas & 79.6 & 174.9 & 9.4 & 7.1 \\
\hline Bahia & 74.0 & 168.5 & 7.6 & 6.2 \\
\hline Ceará & 72.9 & 154.9 & 15.6 & 6.9 \\
\hline Maranhão & 92.3 & 131.1 & 6.7 & 8.8 \\
\hline Paraíba & 102.6 & 162.4 & 8.9 & 6.2 \\
\hline Pernambuco & 73.9 & 180.1 & 7.9 & 7.1 \\
\hline Piauí & 102.5 & 162.5 & 8.8 & 6.5 \\
\hline Rio Grande do Norte & 87.8 & 171.4 & 10.8 & 6.6 \\
\hline Sergipe & 81.2 & 183.2 & 13.3 & 6.7 \\
\hline Central West & 56.7 & 164.7 & 10.4 & 7.6 \\
\hline Federal District & 27.6 & 183.6 & 13.6 & 5.6 \\
\hline Goiás & 58.4 & 151.5 & 9.0 & 6.9 \\
\hline Mato Grosso & 71.9 & 146.8 & 10.8 & 8.9 \\
\hline Mato Grosso do Sul & 64.1 & 199.1 & 9.9 & 9.6 \\
\hline Southeast & 45.8 & 188.7 & 12.3 & 5.6 \\
\hline Espírito Santo & 59.6 & 162.5 & 14.3 & 7.4 \\
\hline Minas Gerais & 65.8 & 169.5 & 9.7 & 6.4 \\
\hline Rio de Janeiro & 40.8 & 245.2 & 8.3 & 7.4 \\
\hline São Paulo & 37.0 & 178.1 & 14.9 & 4.4 \\
\hline South & 53.5 & 211.6 & 11.3 & 5.1 \\
\hline Paraná & 57.8 & 192.7 & 12.1 & 5.2 \\
\hline Rio Grande do Sul & 44.3 & 259.5 & 9.9 & 5.0 \\
\hline Santa Catarina & 62.1 & 161.5 & 12.5 & 4.9 \\
\hline Centralized spending & 7.5 & 10.9 & 23.1 & 11.6 \\
\hline Total & 66.9 & 189.6 & 33.9 & 18.9 \\
\hline
\end{tabular}

Source: Federal budget spending (earmarked funds) - SIGA Brasil. Population - Brazilian Institute of Geography and Statistics (IBGE). Table prepared by the authors.

The analysis of Federal spending on health as a proportion of GNR showed that health failed to accompany the increase in tax revenue, which indicates low fiscal priority for the health sector. Difficulties in defining stable funding sources for health persisted through the first decade of the $21^{\text {st }}$ century, and it was no coincidence that the political struggle shifted to the regulation of Constitutional provisions on Federal funds for health. There was an ongoing struggle to link health expenditures to national revenue (rather than to the GDP), with successive defeats in both the political and legal arenas.

The study allowed identifying efforts at decentralization of Federal health expenditures to poorer regions of the country, through transfers or direct budgetary outlays, associated with specific policies (mainly primary care and epidemiological surveillance). However, such gains should be analyzed with caution: as shown in the literature, discussion of the Federal government's redistributive role and equity in health financing 
requires examining other issues. These include the distribution of Federal funds as a whole and variations in health needs 25 ; the effects of fiscal federalism, rules for binding health sector resources, and the internal diversity of regions, States, metropolitan areas, and Municipalities 19,26; public-private relations in health financing 27; degrees of progressiveness in taxes that finance health 28; and distribution of resources between social groups 29 . In addition, the low levels of Federal investments pose a serious limitation for reducing health inequalities (one of the main purposes of Federal action), given the heterogeneity of health services supply and access in Brazilian territory.

As for conditioning factors, Federal financing of health in the 2000s reflects the influence of structural variables (the weight of the National Executive in the Brazilian state apparatus 16,17, historical difficulties in health financing 30,31) and institutional variables (health policy history and post-1988 Constitutional and legal rules on the roles of the three levels of government). Such Federal financing also reflects changes implemented since the 1990s, related to decentralization and the configuration of a model for Federal intervention heavily based on standardization linked to financial mechanisms 32 .

The study also identifies influences from the political context on health sector financing. One cannot claim that the health sector as a whole was a high priority during the Lula Administration 33. Several difficulties were related to the Senate's vote not to extend the CPMF (bank transaction tax) in late 2007, precisely when the government launched a new plan for strategic reorientation of the sector, called More Health 34 . In addition, the approval of Law 141 on January 13, 2012 35, frustrated expectations for greater expansion of Federal health funds, maintaining the same criteria for binding Federal funds as provided by Constitutional Amendment 29 of 2000.

On the other hand, the country's political scenario favored changes in the relations between the three levels of government, which contributed to an increase in transfers to States and Municipalities in the Brazilian Ministry of Health's budget. It also fostered the expansion of programs in areas defined as strategic (such as inputs and human resources), with fast growth in funds for the former and difficulties with budget outlay in the latter, related to changes in health education policies 33 .

Another issue relates to the Brazilian Ministry of Health's governance in national health policy, given this financing context. On the one hand, the Brazilian Ministry of Health is still recognized as the legitimate national health authority. This can be explained in part by the historical weight of the National Executive Branch in Brazil. In addition, despite political and administrative decentralization, the Ministry still retains important regulatory power in national policy, associated with Federal norms attached to financial incentives targeting States and Municipalities.

On the other hand, the weakening of factors such as the Federal financial burden may jeopardize the maintenance of national health standards 21 . In addition, the transition from a situation of centralized spending of Federal funds to decentralized management (already present in the 1990s), conditioned by the types and pace of health decentralization models 36,37 , assumed new forms in the early $21^{\text {st }}$ century. It is now possible to identify stronger demands by States and Municipalities to reduce the binding of Federal funds to specific programs, with an aim towards expanding local autonomy in the use of such funds.

Importantly, negotiations between the Federal, State, and Municipal levels gained strength in the last decade, aimed at tripartite coordination of health policy in the country's federative system. In other words, even with the prospects for weakening of the power of Federal induction through financing, it is possible to identify initiatives aimed at changing the Ministry's intervention model, to resume national planning and to strengthen regulation through mechanisms such as negotiation and establishment of formal federative agreements 38 .

However, if the characteristics of Brazil's health financing are not changed in the coming years (including the large weight of private expenditures, the drop in the Federal share of public and total expenditure, instability of funding sources, and the dependency of Federal spending on overall economic growth), the Brazilian Ministry of Health's policy governance may be restricted and the Federal role in reducing inequalities may shrink even further.

In short, the Brazilian Ministry of Health's role in health financing in the last decade has been strained by various factors, including: instability in funding sources; fluctuations in health spending as a proportion of GDP; reduction in the Federal share of total health spending due to the increase in the relative share of States and Municipalities in public spending and the persistence of high private expenditures; limited and erratic Federal investments; a progressive increase in direct Federal transfers to other levels of government, while reducing the Ministry's power over application of the resources. This set of factors limits Federal redistributive capacity. 
Strategic challenges thus remain in health financing: to consolidate stable sources of funds for the health sector; to restrict direct and indirect subsidies to the private sector; to expand the public share of health sector financing and the
Federal share of public spending; and to direct Federal resources to strategic areas and to reduce inequalities, aiming at improving health conditions for the Brazilian population as a whole.

\section{Resumen}

Analizamos los cambios de la participación federal en el financiamiento de la salud, durante los años 2000, centrándonos en la ejecución presupuestaria del Ministerio de Salud de Brasil. El estudio registró menor inestabilidad de 2000 a 2002, con mayor crecimiento del gasto federal desde 2006. Sin embargo, el gasto osciló como proporción del PBI y de la recaudación bruta federal. La participación presupuestaria de las transferencias intergubernamentales aumentó a un 70\% en 2007. En lo referente a las inversiones la proporción fue más baja, variando de un 3,4\% a un 6,3\% entre 2002 y 2011. El mayor volumen de gastos correspondió al programa de asistencia hospitalaria y ambulatoria especializada y al aumento relativo a la asistencia farmacéutica e insumos estratégicos. Existen esfuerzos de desconcentración de recursos hacia regiones con falta de recursos -mediante programas de atención básica y vigilancia- insuficientes para superar desigualdades regionales. Las características del financiamiento de la política de salud limitan la gobernabilidad federal y representan un desafío para el Sistema Único de Salud.

Financiación de la Atención de la Salud; Política de Salud; Gobierno Federal

\section{Contributors}

C. V. Machado and L. D. Lima designed the article, conducted the data survey and analysis, and wrote the article. C. L. T. Andrade participated in the data processing and analysis, elaboration of illustrations, and writing of the article. All the authors approved the final version for publication.

\section{Acknowledgements}

C. V. Machado and L. D. Lima currently receive scientific productivity scholarships from CNPq and formerly held Young Scientist scholarships from FAPERJ, from 2009 to 2012. The research project that resulted in the article received funding from the Program to Support Research, Development, and Innovation in Public Health of the National School of Public Health/Fiocruz (Inova-ENSP). 


\section{References}

1. Offe C. Problemas estruturais do estado capitalista. Rio de Janeiro: Tempo Brasileiro; 1984.

2. Esping-Andersen G. As três economias políticas do Welfare State. Lua Nova 1991; 24:85-116.

3. Pierson P. The new politics of the welfare state. New York: Oxford University Press; 2001.

4. Mesa-Lago C. Reassembling social security. New York: Oxford University Press; 2007.

5. Paim J, Travassos C, Almeida C, Bahia L, Macinko J. The Brazilian Health System: history, advances and challenges. Lancet 2011; 377:1778-97.

6. Faveret ACSC. A vinculação constitucional de recursos para a saúde: avanços, entraves e perspectivas. Ciênc Saúde Coletiva 2003; 8:371-8.

7. Dain S. Os vários mundos do financiamento da saúde no Brasil: uma tentativa de integração. Ciênc Saúde Coletiva 2007; 12 Suppl:1851-64.

8. Ugá MAD, Marques RM. O financiamento do SUS: trajetória, contexto e constrangimentos. In: Lima NT, Gerschman S, Edler FC, Suárez JM, organizadores. Saúde e democracia: história e perspectivas do SUS. Rio de Janeiro: Editora Fiocruz; 2005. p. 193-233.

9. Lima LD. Federalismo fiscal e financiamento descentralizado do SUS: balanço de uma década expandida. Trab Educ Saúde 2009; 6:573-97.

10. Piola SF, Vianna S. Saúde no Brasil: algumas questões sobre o Sistema Único de Saúde (SUS). Brasília: Comissão Econômica para a América Latina e Caribe/Instituto de Pesquisa Econômica Aplicada; 2009.

11. World Health Organization. The world health statistics, 2012. Geneva: World Health Organization; 2012 .

12. Bahia L. O sistema de saúde brasileiro entre normas e fatos: universalização mitigada e estratificação subsidiada. Ciênc Saúde Coletiva 2009; 14:753 62.

13. Porto SM, Ugá MAD, Moreira RS. Uma análise da utilização de serviços de saúde por sistema de financiamento: Brasil 1998-2008. Ciênc Saúde Coletiva $2011 ; 16: 3795-806$

14. Servo L, Piola SF, Paiva AB, Ribeiro JA. Financiamento e gasto público de saúde: histórico e tendências. In: Melamed C, Piola SF, organizadores. Políticas públicas e financiamento federal do Sis tema Único de Saúde. Brasília: Instituto de Pesquisa Econômica Aplicada; 2011. p. 85-108.

15. Levi ML, Scatena JHG. Evolução recente do financiamento do SUS e considerações sobre o processo de regionalização. In: Viana AL, Lima LD, organizadoras. Regionalização e relações federativas na política de saúde no Brasil. Rio de Janeiro: ContraCapa; 2011. p. 81-113.

16. Almeida MHT. O estado no Brasil contemporâneo. In: Melo CR, Sáez MA, organizadores. A democracia brasileira: balanço e perspectivas para o século 21. Belo Horizonte: Editora UFMG; 2007. p. 17-34.

17. Arretche M. Continuidades e descontinuidades da federação brasileira: de como 1988 facilitou 1995. Dados 2009; 52:377-423.
18. Souza C. Governos e sociedades locais em con textos de desigualdades e descentralização. Ciênc Saúde Coletiva 2002; 7:431-42.

19. Lima LD, Andrade CLT. Condições de financiamento em saúde nos grandes municípios do Brasil. Cad Saúde Pública 2009; 15:2237-48.

20. Scatena JHG, Viana ALA, Tanaka OY. Sustentabilidade financeira e econômica do gasto público em saúde no nível municipal: reflexões a partir de dados de municípios mato-grossenses. Cad Saúde Pública 2009; 25:2433-45.

21. France G. Compatibilità fra il federalismo e gli standard sanitari nazionali: una sintesi delle esperienze estere e possibili lezioni per l'Italia. In: France G, organizador. Federalismo, regionalismo e Standard Sanitari Nazionali: quattro paesi, quattro approcci. Milano: Dott. A. Giuffrè Editore; 2001. p. 169-97.

22. Banting K, Corbett S. Federalismo y políticas de atención a la salud. In: Auclair C, Carrasco CHG editores. Federalismo y políticas de salud: descentralización y relaciones intergubernamentales desde una perspectiva comparada. Ottawa: Foro de Federaciones/Ciudad de México: Instituto Nacional para el Federalismo y Desarrollo Municipal; 2002. p. 5-41.

23. Watts RL. Comparing federal systems in the 1990s. Kingston: Institute of Intergovernmental Relations, Queen's University; 1996.

24. Instituto de Pesquisa Econômica Aplicada. 15 anos de gasto social federal. Notas sobre o período de 1995 a 2009. Brasília: Instituto de Pesquisa Econômica Aplicada; 2011. (Comunicado do Ipea, 98).

25. Porto SM. Equidad y distribución geográfica de recursos financieros en los sistemas de salud. Cad Saúde Pública 2002; 18:939-57.

26. Vazquez DA. Efeitos da regulação federal sobre o financiamento da saúde. Cad Saúde Pública 2011; 17:1201-12.

27. Santos IS, Ugá MAD, Porto SM. O mix público-privado no Sistema de Saúde Brasileiro: financiamento, oferta e utilização de serviços de saúde. Ciênc Saúde Coletiva 2008; 13:1431-40.

28. Ugá MAD, Santos IS. Uma análise da progressividade do financiamento do Sistema Único de Saú de (SUS). Cad Saúde Pública 2006; 22:1597-609.

29. Cohn A. Eqüidade, saúde e critérios para alocação de recursos. Ciênc Saúde Coletiva 2005; 10:287-8.

30. Piola SF. Comentário: financiamento dos serviços de saúde pública nos últimos 40 anos. Rev Saúde Pública 2006; 40:573-5.

31. Porto SM. Comentário: avanços e problemas no financiamento da saúde pública no Brasil (19672006). Rev Saúde Pública 2006; 40:576-8.

32. Machado CV. O modelo de intervenção do Ministério da Saúde nos anos 90. Cad Saúde Pública 2007; 23:2113-26.

33. Machado CV, Baptista TWF, Lima LD. Políticas de saúde no Brasil: continuidades e mudanças. Rio de Janeiro: Editora Fiocruz; 2012 
34. Machado CV, Lima LD, Baptista TWF, Castro ALB. Política de saúde no governo Lula: continuidades e mudanças. Revista de Política, Planejamento e Gestão em Saúde 2010; 1:11-31.

35. Brasil. Lei Complementar no 141, de 13 de janeiro de 2012. Diário Oficial da União 2012; 16 jan.

36. Levcovitz E, Lima LD, Machado CV. Política de saúde nos anos 90: relações intergovernamentais e papel das normas operacionais básicas. Ciênc Saúde Coletiva 2001; 6:269-91.
37. Viana ALA, Lima LD, Oliveira RG. Descentralização e federalismo: a política de saúde em um novo contexto - lições do caso brasileiro. Ciênc Saúde Coletiva 2002; 7:493-507.

38. Machado CV, Baptista TWF, Lima LD. O planejamento nacional da política de saúde no Brasil: estratégias e instrumentos nos anos 2000. Ciênc Saúde Coletiva 2010; 15:2367-82.

Submitted on 29/Sep/2012

Final version resubmitted on 11/Apr/2013

Approved on 10/Jul/2013 